\title{
NUMBER SENSE SISWA SMK PADA TUGAS MATEMATIS BERBASIS PERTANIAN
}

\author{
Ai Tusi Fatimah ${ }^{1,2}$, Wahyudin ${ }^{2}$ \\ 1 Program Studi Pendidikan Matematika, Universitas Galuh, JI. R. E. Martadinata No.150, Ciamis, Indonesia \\ 2 Program Studi Pendidikan Matematika, Universitas Pendidikan Indonesia, JI. Dr. Setiabudi No. 229, Bandung, \\ Indonesia \\ Email: tusi.fatimah@gmail.com
}

\begin{abstract}
Problem-solving in agriculture involves a lot of numbers and operations. Number sense is part of the number of operation skills. Number sense skill development can be done in learning interactions that are facilitated by mathematical tasks. Agricultural-based mathematical tasks in this study are cognitive interaction tools between teachers, students, and mathematics designed in agricultural problem situations. This case study research will describe the number of sense of vocational students during mathematics learning taking place in the topics of rational numbers, surds, powers, and logarithms. Students who participated in this study of food crops and horticulture agribusiness of 10th grade, as many as 25 people. Data obtained from student answers, interviews, and observations. The data obtained are identified and classified based on the number of sense that appears throughout the study. The results of the research show that the students' number sense at solving tasks is substitution, representation, and approximation. The number sense that appears in influenced by the task situation. Students' knowledge and experience during agricultural practice are supporting factors for students' number sense ability.
\end{abstract}

Keywords: Agriculture, number sense, mathematical task

\begin{abstract}
ABSTRAK
Pemecahan masalah pada bidang pertanian banyak melibatkan bilangan dan operasinya. Number sense merupakan bagian dari keterampilan operasi bilangan. Pengembangan keterampilan number sense dapat dilakukan dalam interaksi pembelajaran yang difasilitasi oleh tugas matematis. Tugas matematis berbasis pertanian pada penelitian ini merupakan alat interaksi kognitif antara guru, siswa, dan matematika yang dirancang dalam situasi masalah pertanian. Penelitian studi kasus ini akan mendeskripsikan number sense siswa SMK selama pembelajaran matematika berlangsung dalam topik bilangan rasional, bentuk akar, pangkat, dan logaritma. Siswa yang berpartisipasi dalam penelitian ini adalah siswa kelas X Kompetensi Keahlian Agribisnis Tanaman Pangan dan Hortikultura, sebanyak 25 orang. Data penelitian diperoleh dari jawaban siswa, wawancara, dan observasi. Data yang diperoleh diidentifikasi dan diklasifikasikan berdasarkan number sense yang muncul sepanjang penelitian. Hasil penelitian menunjukkan bahwa number sense siswa pada penyelesaian tugas adalah kemampuan substitusi, representasi, dan aproksimasi. Number sense yang muncul tersebut dipengaruhi oleh situasi tugas. Selain itu, pengetahuan dan pengalaman siswa dalam praktik pertanian menjadi faktor pendukung kemampuan number sense siswa.
\end{abstract}

Kata kunci: Number sense, pertanian, tugas matematis

Dikirim: 1 Maret 2020; Diterima: 25 Agustus 2020; Dipublikasikan: 30 September 2020

Cara sitasi: Fatimah, A. T., \& Wahyudin. (2020). Number sense siswa smk pada tugas matematis berbasis pertanian. Teorema: Teori dan Riset Matematika, 5(2), 133-142. 


\section{PENDAHULUAN}

Matematika memiliki peran penting dalam bidang pertanian. Petani tidak hanya menggunakan keterampilan praktis namun juga membutuhkan keterampilan matematis (Muhrman, 2015). Untuk mendukung keterampilan matematis tersebut, maka kurikulum sekolah menengah kejuruan bidang pertanian di Indonesia memberikan keterampilan matematis untuk mendukung mempersiapkan petani-petani masa depan yang siap bekerja di bidang pertanian secara profesional. Rasor menyatakan bahwa pengetahuan dan pemahaman matematis yang harus dimiliki siswa pertanian yaitu pengetahuan tentang perhitungan sederhana dan pemahaman metode statistik dan probabilitas untuk menunjang interpretasi hasil eksperimen (C, 1923).

Perhitungan merupakan bagian dari standar matematika sekolah yaitu memahami bilangan dan operasinya (NCTM, 2000). Number sense dan kelancaran aritmatika siswa dari tingkat TK hingga kelas 12 merupakan inti dari standar ini. Number sense merupakan kemampuan menggunakan tolak ukur, estimasi, atau bilangan besar (Yang, 2005). Number sense merupakan kemampuan menggunakan tolok ukur secara tepat atau mengenali besaran bilangan (Yang et al., 2009). Number sense merupakan kemampuan menggunakan tolok ukur yang tepat; menggunakan angka secara fleksibel ketika menghitung; memperkirakan; dan menilai kewajaran hasil; memahami efek relatif dari operasi; dan menguraikan atau menyusun ulang angka untuk memecahkan masalah (Alsawaie, 2012). Number sense merupakan bagian dari keterampilan menghitung dan dasar bilangan yang meliputi representasi bilangan kecil dan representasi aproksimasi bilangan (Slusser, 2019).

Number sense banyak dibutuhkan dalam berbagai pemecahan masalah, baik dalam pemecahan masalah yang melibatkan konten matematika maupun kontekstual (masalah di luar matematika). Number sense terlibat dalam memecahkan masalah aritmatika dasar (Alsawaie, 2012) dan masalah dalam konten matematika lainnya. Number sense dibutuhkan dalam pemecahan masalah yang berhubungan dengan budaya (Wagner \& Davis, 2010). Hasil penelitian Can \& Özdemir (2020) menunjukkan bahwa siswa lebih berhasil dalam menyelesaikan tugas matematika tanpa konteks dibandingkan dengan tugas kontekstual. Di SMK, siswa akan selalu menghadapi masalah-masalah kontekstual sesuai dengan keahliannya. Oleh karena itu, pengembangan number sense siswa SMK hendaknya berfokus pada tugas matematis yang bersifat kontekstual.

Tugas matematis merupakan artefak untuk pembelajaran matematika yang berfungsi sebagai alat interaksi antara guru, siswa, dan matematika (Johnson et al., 2017) yang merujuk pada sosio-didactical tetrohedron (Rezat \& Stra"ßer, 2012). Tugas matematis berbasis pertanian merupakan tugas yang dirancang dalam situasi pertanian. Perancangan tugas matematis ini ditujukan agar memenuhi tuntutan matematika pada dunia kerja. Muhrman (2015) menyatakan bahwa selama ini pembelajaran masih terpisah tidak sesuai konteks. Selain itu, gap antara matematika yang digunakan di sekolah dan di tempat kerja banyak terjadi di sekolah-sekolah kejuruan (LaCroix, 2014; Roth, 2014; Swanson, 2014).

Melalui rancangan tugas matematis berbasis pertanian ini, guru matematika akan berupaya melibatkan diri dengan petani dan profesional untuk mendapatkan situasi masalah yang menghubungkan matematika dengan pertanian. Hal tersebut dilakukan sebagai upaya meminimalisir gap yang terjadi antara matematika yang diajarkan di sekolah dengan yang digunakan di tempat kerja. Salah satu contoh program untuk meningkatkan pengetahuan, persepsi, dan apresiasi guru terhadap industri pertanian adalah The Teacher Farm Experience (Cosbya et al., 2019). Meskipun secara spesifik program tersebut belum menyentuh ranah pendidikan matematika, namun program tersebut dapat dikembangkan dalam ranah pendidikan matematika sehingga mewujudkan matematika yang benar-benar digunakan di bidang pertanian. Program multidisipliner (matematika dan pertanian) juga diharapkan mampu mendukung mempersiapkan siswa sebagai lulusan yang siap bekerja di industri pertanian (Wilkes \& Burns, 2019).

Penelitian terkait pengembangan tugas matematis berbasis pertanian masih jarang ditemukan. Pada bidang keahlian kejuruan lain misalnya, Bakker et al. (2014) merancang alat 
komputer untuk mengembangkan kemampuan penalaran proporsional dalam perhitungan konsentrasi zat kimia saat. Selain itu, Coben \& Weeks (2014) melakukan penelitian terkait rancangan interdisipliner tentang masalah perhitungan dosis obat. Contoh-contoh penelitian tersebut menunjukkan pentingnya keterampilan berhitung siswa. Pada penelitian ini, keterampilan berhitung melibatkan number sense. Oleh sebab itu, tujuan penelitian ini adalah menggali kemampuan number sense yang muncul ketika siswa menyelesaikan tugas matematis berbasis pertanian.

\section{METODE PENELITIAN}

Metode penelitian ini adalah studi kasus. Rancangan ini dipilih karena objek dan subjek yang diamati bersifat spesifik. Objek yang diamati adalah kemampuan number sense pada saat siswa menyelesaikan tugas matematis berbasis pertanian yang dirancang pada topik bilangan rasional, bentuk pangkat, dan logaritma. Subjek penelitian adalah siswa kelas X, SMK Kompetensi Keahlian Tanaman Pangan dan Hortikultura di Ciamis, Indonesia sebanyak 25 orang.

Pengambilan data dilakukan melalui tugas matematis yang dirancang dalam situasi pertanian. Tugas tersebut disajikan pada Tabel 1. Tugas-tugas tersebut diberikan kepada siswa setelah memperoleh setiap topik pembelajaran. Selama proses penyelesaian tugas, siswa diobservasi dan dilakukan dokumentasi dengan video dan audio. Selain itu, dilakukan analisis lembar jawaban siswa dan transkrip wawancara siswa yang memiliki kasus tertentu berdasarkan data hasil observasi.

Tabel 1. Tugas matematis berbasis pertanian

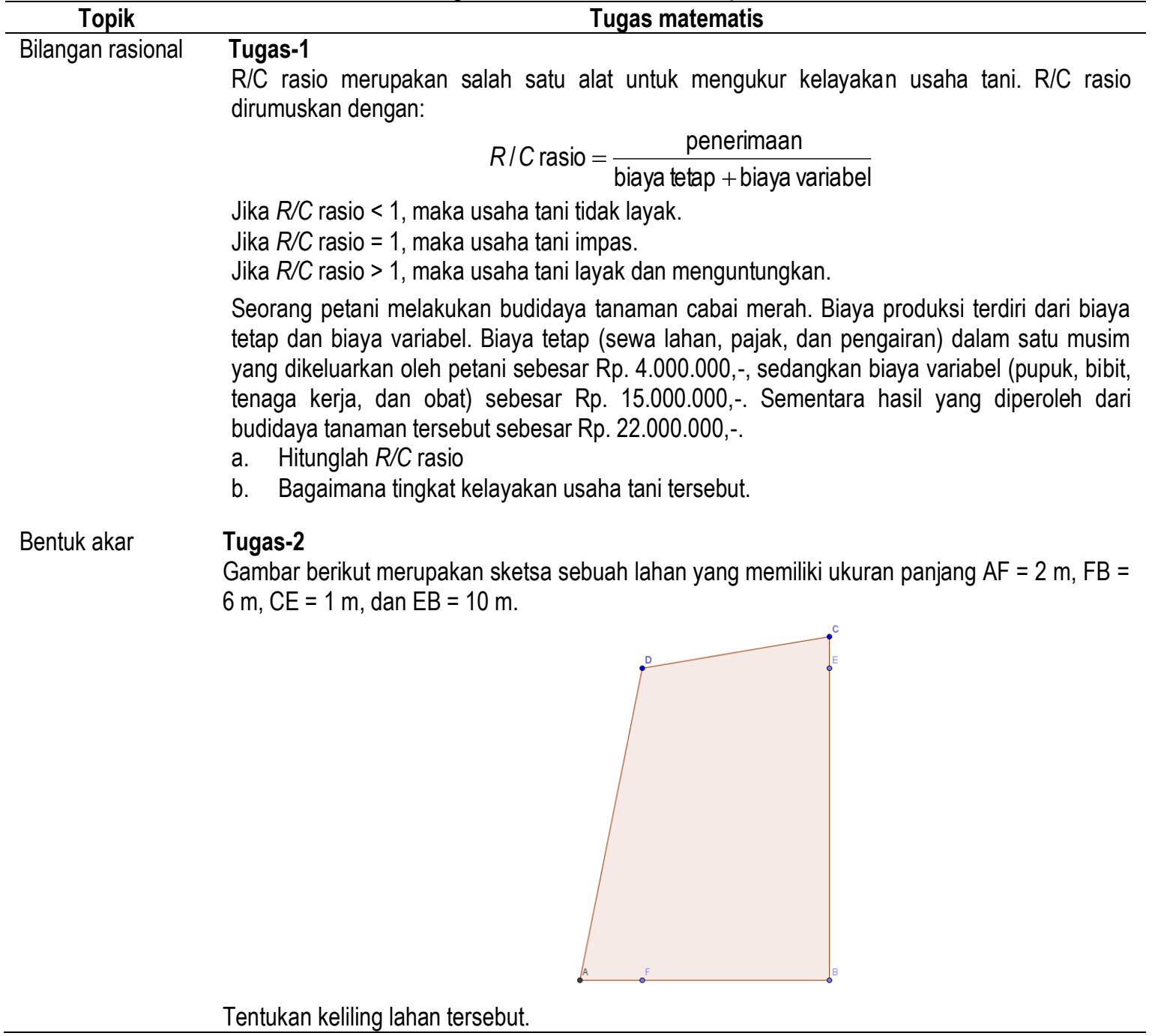


Lanjutan Tabel 1.

Tabel 1. Tugas matematis berbasis pertanian

\begin{tabular}{|c|c|}
\hline Topik & Tugas matematis \\
\hline Bentuk pangkat & $\begin{array}{l}\text { Tugas-3 } \\
\text { Banyaknya fungisida yang diperlukan untuk menyemprot lahan seluas } 1 \mathrm{Ha} \text { adalah } 1000 \mathrm{cc} \text {. } \\
\text { Seorang petani memiliki lahan } 5 \text { bata. Berapa liter fungisida yang dibutuhkan? Tulis jawaban } \\
\text { akhirnya dalam bentuk notasi ilmiah. } \\
\left(1 \mathrm{Ha} \approx 10000 \mathrm{~m}^{2}, 1 \text { liter }=1000 \mathrm{cc}, 1 \text { bata } \approx 14 \mathrm{~m}^{2}\right) .\end{array}$ \\
\hline \multirow[t]{3}{*}{ Logaritma } & Tugas-4 \\
\hline & $\begin{array}{l}\text { Derajat keasaman suatu larutan }(\mathrm{pH}) \text { bergantung pada konsentrasi } \mathrm{H}^{+} \text {dalam larutan. Nilai } \mathrm{pH} \\
\text { larutan dapat dihitung dengan menggunakan rumus: } \\
\qquad \mathrm{pH}=-\log \left[\mathrm{H}^{+}\right] .\end{array}$ \\
\hline & $\begin{array}{l}\text { Suatu larutan hidroponik memiliki konsentrasi ion } \mathrm{H}^{+} \text {sebesar } 7 \cdot 10^{-5} \text {. Tentukan nilai pH } \\
\text { larutan tersebut. }\end{array}$ \\
\hline
\end{tabular}

Data-data yang diperoleh kemudian diidentifikasi dan diklasifikasikan berdasarkan number sense yang muncul dengan cara membandingkannya dengan teori-teori number sense dari penelitian-penelitian sebelumnya (Yang, 2005; Yang et al., 2009; Alsawaie, 2012; Slusser, 2019).

\section{HASIL PENELITIAN}

Setiap respon siswa diidentifikasi dan diklasifikasi untuk menggali kemampuan number sense yang muncul dalam penyelesaian tugas. Berikut ini adalah kasus-kasus dari respon siswa pada setiap tugas yang diberikan.

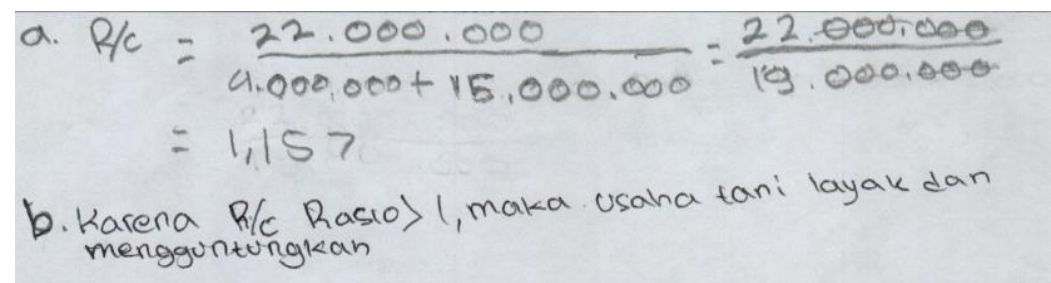

\section{Gambar 1. Respon siswa pada tugas-1}

Gambar 1 menunjukkan kemampuan siswa dalam mensubstitusikan bilangan-bilangan pada situasi tugas ke dalam formula yang diberikan, melakukan perhitungan, pembulatan, dan menarik kesimpulan. Semua siswa dapat melakukan proses substitusi dengan benar. Pada proses perhitungan, beberapa siswa melakukannya dengan bantuan kalkulator dan sebagian besar melakukannya dengan teknik pembagian bersusun. Gambar 1 menunjukkan hasil dari perhitungan dengan pembagian bersusun sampai tiga angka di belakang koma. Di sisi lain, siswa yang menggunakan kalkulator menghasilkan jawaban 1,1578947368 dan membulatkannya menjadi 1,158. Ada juga siswa yang masih bertanya proses pembulatan pada guru. Pada proses terakhir, siswa dapat menarik kesimpulan dengan membandingkan bilangan yang dihasilkan pada bagian a dengan aturan yang diberikan pada tugas. Mereka mengetahui bahwa bilangan 1,157 lebih besar dari 1 dan dapat menyimpulkan bahwa usaha tani layak dan menguntungkan. 


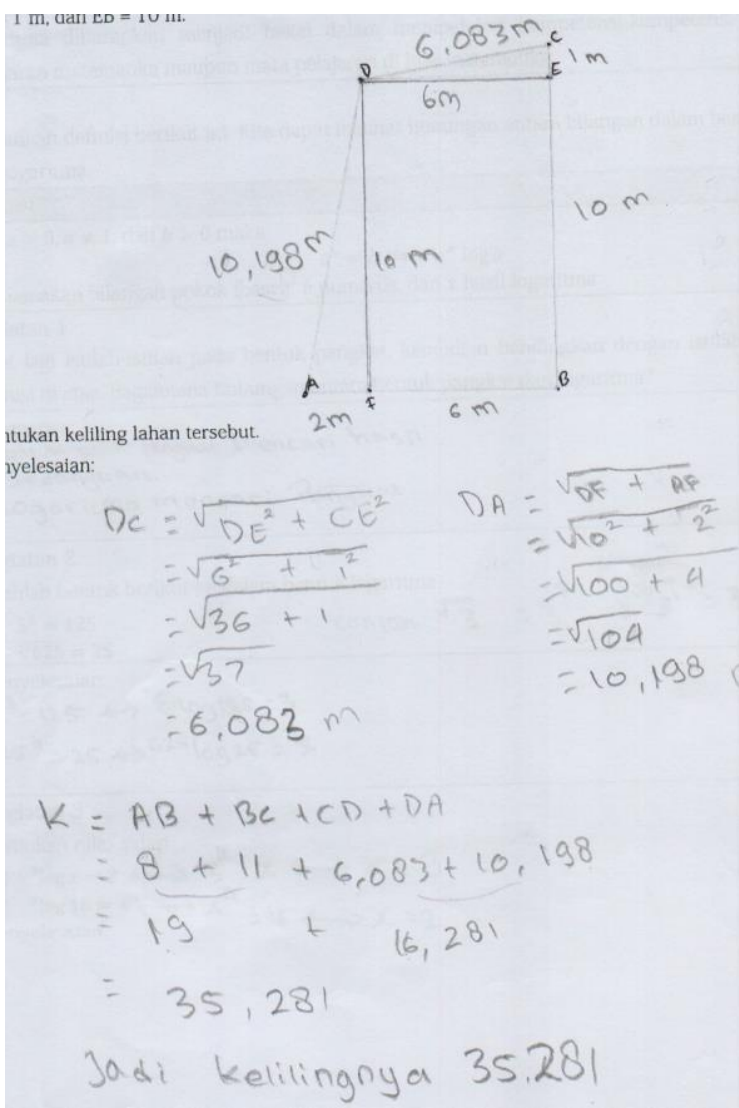

(a)

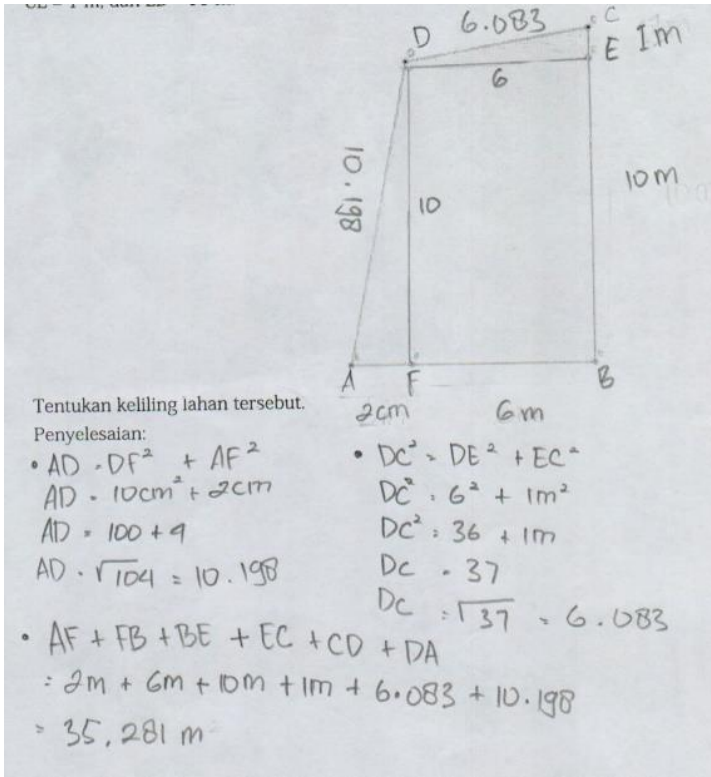

(b)

Gambar 2. Respon siswa pada tugas-2

Gambar 2 menunjukkan bahwa siswa dapat menganalogikan ukuran-ukuran yang tersedia pada tugas terhadap ukuran-ukuran yang belum diketahui pada bidang (lahan) sehingga siswa dapat menentukan ukuran DE dan DF. Semua siswa dapat melakukannya dengan baik. Selanjutnya, siswa terlihat merenung sejenak, mencoba berpikir strategi penyelesaian untuk menentukan ukuran sisi-sisi lahan yang belum diketahui. Tiba-tiba ada seorang siswa berkata, "Ini pakai phytagoras!". Pernyataan siswa ini kemudian menjadi ide bagi siswa lain dalam penyelesaian tugas ini.

Gambar 2 menunjukkan cara pengimplementasian teorema phytagoras dari dua orang siswa. Pada jawaban bagian (b), siswa tidak konsisten menuliskan rumus phytagoras, sekalipun jawaban akhirnya benar. Selanjutnya, siswa mengubah bilangan dalam bentuk akar menjadi bentuk bilangan desimal dengan bantuan kalkulator dan melakukan pembulatan. Terakhir, siswa menghitung keliling lahan dengan menjumlahkan semua panjang sisi-sisi lahan.

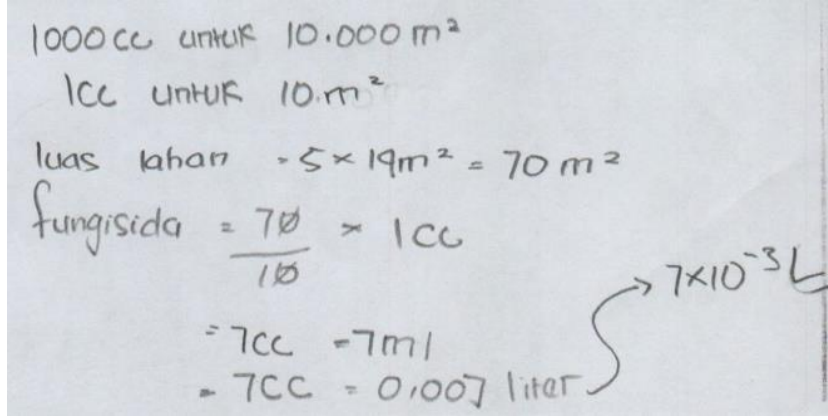

Gambar 3. Respon siswa pada tugas-3

Pada awal penyelesaian tugas-3, siswa terlihat bingung. Siswa saling bertanya: "Ini harus bagaimana?". Kemudian siswa membaca ulang situasi tugas. Kemudian ada siswa yang bergumam: 
"Ini 10.000 dibagi 1.000 begitu?.."

"Oh..jadi nantinya 10.."

"Nanti 10 nya dibagaimanakan?"

"dibuat ke bata?"

Siswa tersebut berusaha merepresentasikan bilangan-bilangan pada situasi tugas dengan melakukan perbandingan kebutuhan fungisida terhadap luas lahan. Kemudian mengonversi satuan bata terhadap meter persegi dan membuat hubungan (operasi) antara bilangan-bilangan yang dihasilkan. Setelah melakukan perhitungan, siswa mengubah bentuk bilangan desimal ke dalam bentuk pangkat.

Pada penyelesaian tugas-3 ini, hanya empat puluh persen siswa yang dapat menyelesaikannya. Berdasarkan wawancara, siswa tidak dapat melakukan perbandingan kebutuhan fungisida terhadap luas lahan dan membuat hubungan bilangan-bilangan.

$$
\begin{aligned}
& P H=-\log 7.10^{-5} \\
& P H=-\log -700000 \\
& P H=-(-700000) \log \\
& P H=700000 \\
& J \text { adi, nilarpHlarutan tersebut }=700000
\end{aligned}
$$

(a)

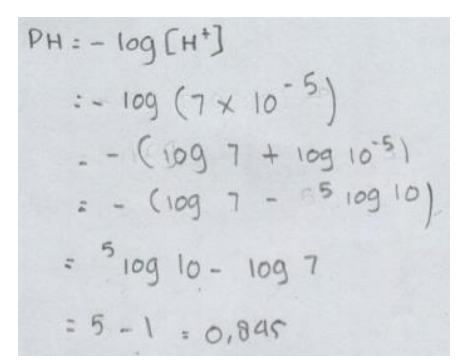

(b)

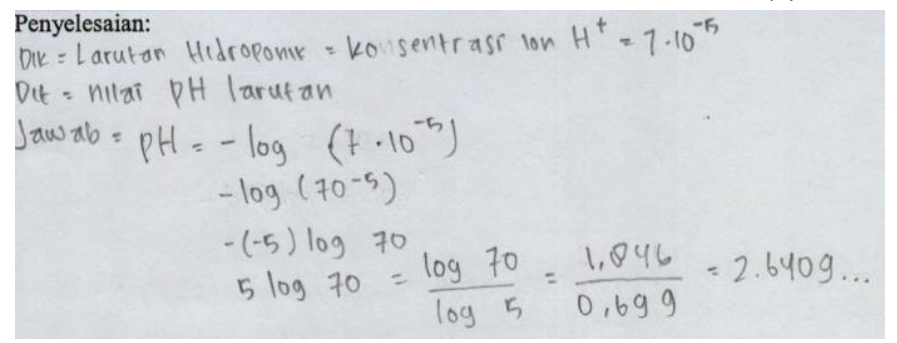

(c)

Gambar 4. Respon siswa pada tugas-4

Gambar 4 menunjukkan respon siswa pada tugas-4. Siswa terlihat dapat mensubstitusikan bilangan pada formula yang diberikan namun siswa belum dapat melakukan operasi logaritma dan bentuk pangkat. Berdasarkan wawancara, siswa belum memahami sifat-sifat logaritma dan bentuk pangkat.

\section{PEMBAHASAN}

Hasil observasi, lembar jawaban siswa, dan wawancara menunjukkan bahwa number sense yang muncul dalam penyelesaian tugas matematis berbasis pertanian adalah kemampuan substitusi, representasi bentuk-bentuk bilangan (konversi bentuk bilangan), dan aproksimasi. Kemampuan number sense yang muncul pada setiap tugas berbeda-beda bergantung situasi masalah pada tugas. Berikut akan dibahas masing-masing kemampuan number sense yang ditemukan.

Pertama, substitusi. Kemampuan ini muncul pada tugas-1, tugas-2, dan tugas-4. Kemampuan ini berkaitan dengan kemampuan siswa mengimplementasikan setiap bilangan pada konteks tugas terhadap variabel-variabel dalam formula. Setidaknya terdapat dua kemampuan yang terhubung dalam kasus number sense ini yaitu korespondensi (Greeno, 1978) dan aritmatika (Alsawaie, 2012). Melalui kemampuan korespondensi, siswa dapat menghubungkan konteks dengan konsep matematis. Pada tugas-1 dan tugas-4, formula sudah ditentukan sedangkan pada tugas-2 
formula (phytagoras) belum ditentukan. Artinya, pada tugas-1 dan tugas-4 substitusi dapat langsung dilakukan sedangkan pada tugas-2 diperlukan pengetahuan konseptual matematis terlebih dahulu. Namun demikian, untuk melakukan substitusi, siswa harus mampu menghubungkan konteks dengan variabel-variabel pada formula. Selanjutnya, proses substitusi terhubung dengan kemampuan aritmetika yang didalamnya diperlukan pengetahuan prosedur-prosedur operasi bilangan. Berdasarkan temuan-temuan tersebut, jelaslah bahwa number sense dapat dipengaruhi oleh pengetahuan kontekstual, konseptual, dan prosedural matematis yang dimiliki siswa sehingga mendukung rangkaian penyelesaian tugas. Kejadian ini selaras dengan hasil penelitian Fatimah, et al. (2020) bahwa pengetahuan kontekstual, konseptual, dan prosedural menjadi penentu keberhasilan dalam penyelesaian tugas.

Kedua, representasi. Kemampuan ini dapat ditemukan pada tugas-2 dan tugas-3. Pada tugas-2, terjadi representasi bentuk bilangan dari bentuk akar ke dalam bentuk desimal. Pada tugas-3, terjadi konversi satuan yang mengakibatkan perubahan kuantitas bilangan (sangat besar atau sangat kecil) dan dapat direpresentasikan dalam bentuk pangkat. Kejadian pada kedua tugas tersebut menuntun siswa memiliki kemampuan fleksibilitas pada bilangan (Gersten \& Chard, 1999).

Representasi bilangan dalam bentuk desimal banyak digunakan dalam suatu konteks praktis atau realitas lapangan. Misalnya dalam tugas-2, ukuran panjang lahan biasanya direpresentasikan dalam bentuk desimal dan tidak lazim digunakan bentuk akar. Di sisi lain, tugas-3 menuntut siswa untuk merepresentasikan bilangan dalam bentuk pangkat yang tidak lazim dilakukan petani. Dua keadaan ini menunjukkan bahwa realita di dunia pertanian dapat ditarik ke dalam kelas pembelajaran matematika dan begitu juga sebaliknya. Dalam hal ini, matematika dalam pendidikan kejuruan memiliki dua muka (Bakker et al., 2014), yaitu konseptual matematis dan matematika yang digunakan secara praktis.

Ketiga, aproksimasi bilangan. Kemampuan ini dapat ditemukan pada tugas-1, tugas-2, dan tugas 4. Terdapat dua teknik yang dilakukan siswa saat proses ini dilakukan. Siswa melakukan pembulatan bilangan dari hasil operasi yang dilakukan dengan bantuan alat hitung dan siswa melakukan pemotongan hasil perhitungan dengan teknik pembagian bersusun. Secara tidak langsung guru memberikan dua metode aproksimasi bilangan yaitu membulatkan dan memotong (Ascher \& Greif, 2011). Pemilihan metode aproksimasi bilangan tersebut dapat dilakukan sesuai dengan konteks tugas yang diberikan. Pada kasus aproksimasi tugas-1, tugas-2, dan tugas-4 dapat dilakukan kedua metode tersebut.

Solusi dari tugas matematis yang diberikan kepada siswa berupa bilangan-bilangan yang harus direpresentasikan secara masuk akal sesuai dengan konteks tugas. Kemasukakalan penyelesaian dan solusi tugas matematis dalam masalah-masalah keahlian kejuruan atau masalahmasalah bersifat kontekstual merupakan temuan penting dalam penelitian pada area pendidikan kejuruan (misalnya Fatimah \& Zakiah, 2018). Kemasukakalan dalam substitusi terjadi ketika menghubungkan bilangan-bilangan pada konteks dengan variabel pada formula, pada saat representasi bilangan dilakukan mengikuti kebiasaan realitas di lapangan, dan aproksimasi harus disesuaikan dengan konteks tugas yang diberikan.

Konteks tugas yang diberikan mempengaruhi number sense siswa yang muncul selama penyelesaian tugas. Dalam hal ini, perancangan tugas memilki peran penting dalam mengembangkan number sense siswa. Sebuah tugas matematis dapat dirancang dengan tujuan mengembangkan satu, dua, atau tiga jenis number sense,bergantung pada tujuan perancangan tugas.

Penelitian-penelitian sebelumnya juga menunjukkan bahwa perancangan tugas dan konteks yang disajikan menentukan kemampuan-kemampuan matematis siswa. Lithner (2017) menyatakan bahwa perancangan tugas matematis dapat mempengaruhi penalaran matematis. Fatimah et al. (2019) menyatakan bahwa konteks agribisnis hortikultura yang tersedia pada tugas membantu penalaran matematis siswa. Fatimah (2016) menyatakan bahwa variasi konteks dapat mengembangkan kemampuan pemecahan masalah siswa. 


\section{KESIMPULAN}

Number sense merupakan keterampilan matematis yang mendukung penyelesaian masalah dalam konteks pertanian. Kemampuan number sense siswa yang muncul bergantung pada rancangan tugas yang disajikan, pengetahuan, dan pengalaman siswa. Rancangan tugas pada penelitian ini hanya mampu mengungkap kemampuan number sense yang meliputi substitusi, representasi, dan aproksimasi bilangan. Pengetahuan dan pengalaman konteks pertanian mendukung kemampuan number sense siswa.

\section{REKOMENDASI}

Number sense di SMK perlu dikembangkan karena pemecahan masalah pada setiap kompetensi keahlian membutuhkannya. Pengembangan number sense dapat dilakukan melalui perancangan tugas matematis dalam berbagai konteks sesuai dengan keahlian siswa. Di Indonesia, area penelitian tentang tugas dan kemampuan matematis yang bersesuaian dengan bidang keahlian kejuruan masih jarang ditemukan. Padahal, pemahaman matematis yang sesuai dengan bidang keahlian merupakan standar kelulusan yang harus dimiliki oleh siswa SMK (Permendikbud Nomor 34 Tahun 2018). Selain itu, penelitian-penelitian tentang kebutuhan matematika di SMK menunjukkan bahwa mata pelajaran bidang/program/kompetensi keahlian membutuhkan konten matematika yang berbeda-beda (Fatimah \& Zakiah, 2019; Fatimah et al., 2019). Oleh karena itu, luasnya area penelitian pada SMK merupakan kesempatan yang sangat terbuka bagi para peneliti yang tertarik pada bidang pendidikan matematika kejuruan.

\section{UCAPAN TERIMAKASIH}

Ucapan terima kasih kami sampaikan kepada Bapak/lbu guru dan siswa siswi yang terlibat dan berpartisipasi dalam penelitian ini.

\section{DAFTAR PUSTAKA}

Alsawaie, O. N. (2012). Number sense-based strategies used by high-achieving sixth grade students who experienced reform textbooks. Int J of Sci and Math Educ, 10, 1071-1097.

Ascher, U. M., \& Greif, C. (2011). A first course in numerical methods. USA: Siam.

Bakker, A., Groenveld, D., Wijers, M., Akkerman, S. F., \& Koeno, P. E. (2014). Gravemeijer proportional reasoning in the laboratory: an intervention study in vocational. Educational Studies in Mathematics, 86, 211-221.

C., N. M. (1923). Mathematics for students of agriculture. Nature, 112, 128-129. https://doi.org/10.1038/112128c0.

Can, D., \& Özdemir, Y. (2020). An examination of fourth-grade elementary school students' number sense in context-based and non-context-based problems. Int J of Sci and Math Educ, 18(7), 1333-1354. https://doi.org/10.1007/s10763-019-10022-3.

Coben, D., \& Weeks, K. (2014). Meeting the mathematical demands of the safety-critical workplace: medication dosage calculation problem-solving for nursing. Educ Stud Math, 86(2), 253-270. doi.10.1007/s10649-014-9537-3.

Cosbya, A., Manninga, J., \& Trottera, M. (2019). TeacherFX - building the capacity of stem, agriculture and digital technologies teachers in western australia. International Journal of Innovation in Science and Mathematics Education, 27(4), 76-87. 
Fatimah, A. T. (2016). Kemampuan pemecahan masalah mahasiswa pada pokok bahasan anuitas dan asuransi. Teorema: Teori dan Riset Matematika, 1(1), 19-26.

Fatimah, A. T., \& Zakiah, N. E. (2018). Kelancaran prosedural matematis dalam pemecahan masalah konteks pemasaran. Mathline: Jurnal Matematika dan Pendidikan Matematika, 3(2), 141-150.

Fatimah, A. T., Effendi, A., \& Amam, A. (2018). Koneksi matematis pada konsep ekonomi (permintaan dan penawaran). Teorema: Teori dan Riset Matematika, 2(2), 107-116.

Fatimah, A. T., Pramuditya, S. A., \& Wahyudin. (2019). Imitative and creative reasoning for mathematical problem solving (in context horticultural agribusiness). Journal of Physics: Conf. Series 1157 042092: 1-6.

Fatimah, A. T., \& Zakiah, N. E. (2019). Matematika pada kompetensi teknik dan bisnis sepeda motor. Jumlahku: Jurnal Matematika IImiah STKIP Muhammadiyah Kuningan, 5(1), 31-47.

Fatimah, A. T., Zakiah, N. E., Sunaryo, Y., Gumilar, I., \& Rusmana, I. (2020). Contextual, conceptual, and procedural knowledge of vocational high school students in solving distance contexts. Jurnal Theorems (The Original Research of Mathematics), 4(2), 147-154.

Gersten, R., \& Chard, D. (1999). Number sense: rethinking arithmetic instruction for students with mathematical disabilities. The Journal of Special Education, 33, 18-28.

Greeno, J. G. (1978). Understanding and procedural knowledge in mathematics instruction. Educational Psychologist, 12(3), 262-283.

Johnson, H. L., Coles, A., \& Clarke, D. (2017). Mathematical tasks and the student: navigating "tensions of intentions" between designers, teachers, and students. ZDM Mathematics Education, 49(6), 813-822.

LaCroix, L. (2014). Learning to see pipes mathematically: preapprentices' mathematical activity in pipe trades training. Educational Studies in Mathematics, 86(2), 157-176.

Lithner, J. (2017). Principles for designing mathematical tasks that enhance imitative and creative reasoning. ZDM Mathematics Education, 49(6), 937-949.

Muhrman, K. (2015). Mathematics in agriculture and vocational education for agriculture. CERME 9Ninth Congress of European Society for Research in Mathematics Education. Charles University in Prague, Faculty of Education; ERME, Feb 2015, Prague, Czech Republic. pp.1669-1670, 01287937.

NCTM. (2000). Principle and standards for school mathematics. USA: NCTM.

Rezat, S., \& Stra"ßer, R. (2012). From the didactical triangle to the socio-didactical tetrahedron: artifacts as fundamental constituents of the didactical situation. ZDM Mathematics Education, 44(6), 641-651.

Roth, W. M. (2014). Rules of bending, bending the rules: the geometry of electrical conduit bending in college and workplace. Educational Studies in Mathematics, 86(2), 177-192. 
Slusser, E. (2019). Counting and basic numerical skills. In: Fritz A., Haase V., Räsänen P. (eds) International Handbook of Mathematical Learning Difficulties. Springer, Cham. https://doi.org/10.1007/978-3-319-97148-3_31.

Swanson, D. (2014). Making abstract mathematics concrete in and out of school. Educational Studies in Mathematics, 86(2), 193-209.

Wagner, D., Davis, B. (2010). Feeling number: grounding number sense in a sense of quantity. Educ Stud Math, 74, 39-51.

Wilkes, J., \& Burnsb, A. (2019). A decade of agriculture graduates' employability and career pathways janelle. International Journal of Innovation in Science and Mathematics Education, 27(4), 2-13.

Yang, D. C. (2005). Number sense strategies used by sixth grade students in taiwan. Educational Studies, 31(3), 317-334.

Yang, D. C., Reys, R. E., \& Reys, B. (2009). Number sense strategies used by pre-service teachers in taiwan. J. Int $\mathrm{J}$ of Sci and Math Educ, 7(2), 383-403. 